\title{
The Effect of Cerium Oxide Nanoparticle Valence State on Reactive Oxygen Species and Toxicity
}

\author{
Katherine M. Dunnick • Rajalekshmi Pillai • \\ Kelly L. Pisane • Aleksandr B. Stefaniak • \\ Edward M. Sabolsky $\cdot$ Stephen S. Leonard
}

Received: 30 January 2015 / Accepted: 3 March 2015 / Published online: 17 March 2015

(C) The Author(s) 2015. This article is published with open access at Springerlink.com

\begin{abstract}
Cerium oxide $\left(\mathrm{CeO}_{2}\right)$ nanoparticles, which are used in a variety of products including solar cells, gas sensors, and catalysts, are expected to increase in industrial use. This will subsequently lead to additional occupational exposures, making toxicology screenings crucial. Previous toxicology studies have presented conflicting results as to the extent of $\mathrm{CeO}_{2}$ toxicity, which is hypothesized to be due to the ability of $\mathrm{Ce}$ to exist in both $a+3$ and +4 valence state. Thus, to study whether valence state and oxygen vacancy concentration are important in $\mathrm{CeO}_{2}$ toxicity, $\mathrm{CeO}_{2}$ nanoparticles were doped with gadolinium to adjust the cation $(\mathrm{Ce}, \mathrm{Gd})$ and anion $(\mathrm{O})$ defect states. The hypothesis that doping would increase toxicity and decrease antioxidant abilities as a result of increased oxygen vacancies and inhibition of +3 to +4 transition was tested. Differences in toxicity and reactivity based on valence
\end{abstract}

Electronic supplementary material The online version of this article (doi:10.1007/s12011-015-0297-4) contains supplementary material, which is available to authorized users.

K. M. Dunnick $(\bowtie) \cdot$ S. S. Leonard

National Institute for Occupational Safety and Health, HELD, 1095

Willowdale Rd, Morgantown, WV 26505, USA

e-mail:kdunnick@mix.wvu.edu

K. M. Dunnick $\cdot$ S. S. Leonard

Pharmaceutical and Pharmacological Sciences, West Virginia

University, Morgantown, WV 26505, USA

R. Pillai $\cdot$ E. M. Sabolsky

Benjamin M. Statler College of Engineering and Mineral Resources, WVU, Morgantown, WV 26505, USA

\section{K. L. Pisane}

Department of Physics and Astronomy, West Virginia University, Morgantown, WV 26505, USA

K. L. Pisane · A. B. Stefaniak

National Institute for Occupational Safety and Health, DRDS,

Morgantown, WV 26505, USA state were determined in RLE-6TN rat alveolar epithelial and NR8383 rat alveolar macrophage cells using enhanced dark field microscopy, electron paramagnetic resonance (EPR), and annexin V/propidium iodide cell viability stain. Results from EPR indicated that as doping increased, antioxidant potential decreased. Alternatively, doping had no effect on toxicity at $24 \mathrm{~h}$. The present results imply that as doping increases, thus subsequently increasing the $\mathrm{Ce}^{3+} / \mathrm{Ce}^{4+}$ ratio, antioxidant potential decreases, suggesting that differences in reactivity of $\mathrm{CeO}_{2}$ are due to the ability of $\mathrm{Ce}$ to transition between the two valence states and the presence of increased oxygen vacancies, rather than dependent on a specific valence state.

Keywords Cerium oxide Valence state $\cdot$ Nanotoxicology . Reactive oxygen species · Toxicity

\section{Introduction}

Cerium oxide $\left(\mathrm{CeO}_{2}\right)$ nanoparticles are useful in a variety of applications, including polishing agents, solar cells, and catalysts; they have also found use as a diesel fuel additive [1,2]. Cerium (Ce), a rare earth metal of the lanthanide series, is the most abundant rare earth metal making research into the production and use of $\mathrm{CeO}_{2}$ nanoparticles desirable. When in the form of $\mathrm{CeO}_{2}$, the $\mathrm{Ce}$ atom can exist in both a trivalent $\left(\mathrm{Ce}^{3+}\right)$ and more stable tetravalent $\left(\mathrm{Ce}^{4+}\right)$ state, allowing the nanoparticles to store and release oxygen [3]. This ability has increased industrial interest into $\mathrm{CeO}_{2}$ and its potential use in catalysts [4]. In fact, production of $\mathrm{CeO}_{2}$ with increased oxygen storage and releasing properties is desirable in industry to increase its catalytic properties. This increased interest will result in growth in the industrial uses of $\mathrm{CeO}_{2}$ and consequently result in greater exposure risks, specifically inhalation risks, for individuals working in the manufacturing process. 
Therefore, to understand and limit potentially toxic inhalation exposures, investigation into the toxicity of $\mathrm{CeO}_{2}$ is crucial.

Studies of the toxicity of this nanomaterial have been completed using various cell types, including pulmonary epithelial cells, macrophages, lung fibroblasts, and endothelial cells, but there have been conflicting results. For example, in pulmonary epithelial cells (BEAS-2B and A549 cells), $\mathrm{CeO}_{2}$ can either exert toxicity mediated by reactive oxygen species (ROS) production [5, 6] and Nrf-2 signaling [7] or has antioxidantlike properties [8]. Additionally, $\mathrm{CeO}_{2}$ has antioxidant-like properties under induced oxidative stress in RAW 264.7 macrophage cells [8] and protective effects against induced apoptosis in U937 and Jurkat lymphocyte cells [9]. These conflicting findings have been hypothesized to be a result of the ability of $\mathrm{Ce}$ to transition between $\mathrm{Ce}^{3+}$ and $\mathrm{Ce}^{4+}$ valence states and the subsequent oxygen vacancies formed from this transition $[3,10]$. The reduction of $\mathrm{Ce}^{4+}$ to $\mathrm{Ce}^{3+}$ is thought to generate superoxide anions, which can produce damaging hydroxyl radicals. It is also postulated that $\mathrm{Ce}^{3+}$ can react with hydroxyl radicals and act as an antioxidant [6, 9-11]. Thus, it is possible that the valence state of $\mathrm{Ce}$ affects whether $\mathrm{CeO}_{2}$ nanoparticles play a protective or toxic role in exposed cells. Based on previous research, we hypothesize that valence state determines the extent of $\mathrm{CeO}_{2}$ toxicity and that when $\mathrm{CeO}_{2}$ exist in a greater $3+/ 4+$ ratio, its toxicity will increase and antioxidant potential will decrease. To test this hypothesis and assess the effects of valence state, a technique known as doping was employed. Doping is the process of intentionally introducing impurities into a pure substance to modulate electrical properties. To modulate the oxygen storage and release capacity of $\mathrm{CeO}_{2}$ nanoparticles, rare earth metal ions with low valence states are typically used [4]. For this study, gadolinium(III) oxide $\left(\mathrm{Gd}_{2} \mathrm{O}_{3}\right)$ was used to produce increased oxygen vacancies in the $\mathrm{CeO}_{2}$ nanoparticle lattice [4] and force the valence state toward a greater $+3 /+4$ ratio. Two types of doped $\mathrm{CeO}_{2}$ nanoparticles were prepared and used for this study, a 10 and $20 \mathrm{~mol} \% \mathrm{Gd}$ in $\mathrm{CeO}_{2}$. In addition, pure $\mathrm{CeO}_{2}$ nanoparticles were tested. Previous studies have shown that $\mathrm{Gd}_{2} \mathrm{O}_{3}$ itself exhibits toxicity [12]; therefore, $\mathrm{Gd}_{2} \mathrm{O}_{3}$ controls were used throughout the study to ensure any differing effects between cerium compounds were due to valence state and transitional ability rather than the presence of $\mathrm{Gd}_{2} \mathrm{O}_{3}$. The effect of valence state and transitional ability of pure $\mathrm{CeO}_{2}$ nanoparticles and doped $\mathrm{CeO}_{2}$ nanoparticles on ROS and toxicity was assessed.

\section{Materials and Methods}

\section{Cell Culture}

RLE-6TN rat alveolar type II cells (ATCC; Rockville, MD) were cultured following a modified ATCC recommended protocol. Cells were cultured in Ham's F12 medium with $5 \%$ fetal bovine serum and $50 \mathrm{mg} / \mathrm{ml}$ penicillin/streptomycin (Thermo Scientific; Pittsburgh, PA). Cells were grown at $37^{\circ} \mathrm{C}$ in a $5 \% \mathrm{CO}_{2}$ incubator and were passaged following trypsinization. RLE-6TN cells were chosen for these studies to represent the pulmonary alveolar region most likely to come into contact with nanoparticles. NR8383 rat macrophage cells (ATCC; Rockville, MD) were cultured following the ATCC recommended protocol. Cells were cultured in Ham's F12K medium with $15 \%$ fetal bovine serum and $50 \mathrm{mg} / \mathrm{ml}$ penicillin/streptomycin. Cells were grown at $37{ }^{\circ} \mathrm{C}$ in a $5 \% \mathrm{CO}_{2}$ incubator and were passaged by transferring floating cells to culture flasks.

\section{$\mathrm{CeO}_{2}$ Nanoparticle Production and Characterization}

Gd-doped $\mathrm{CeO}_{2}$ nanopowder was prepared using a hydrothermal method [13] (Fig. 1). For this process, two separate aqueous solutions $\left(5 \times 10^{-3} \mathrm{~mol} \mathrm{~L}^{-1}\right)$ of cerium (IV) ammonium nitrate $\left(\mathrm{Ce}\left(\mathrm{NH}_{4}\right)_{2}\left(\mathrm{NO}_{3}\right)_{6}, 99.9 \%\right.$ purity), and gadolinium nitrate hexa-hydrate $\left(\mathrm{Gd}\left(\mathrm{NO}_{3}\right)_{3} \cdot 6 \mathrm{H}_{2} \mathrm{O}\right)$ were prepared by dissolving the salts into deionized water at room temperature. The as-prepared solutions were mixed together under vigorous stirring. An aqueous solution of tetramethyl ammonium hydroxide (TMAH) was added drop by drop until the $\mathrm{pH}$ of the solution reached 10 . After $30 \mathrm{~min}$ of stirring, a white or yellowish gel-like precipitate was formed and settled rapidly. The supernatant of the solution was decanted, and the resulting solid was rinsed several times with deionized water and hydrothermally treated at $240{ }^{\circ} \mathrm{C}$ for $1 \mathrm{~h}$ under autogenous

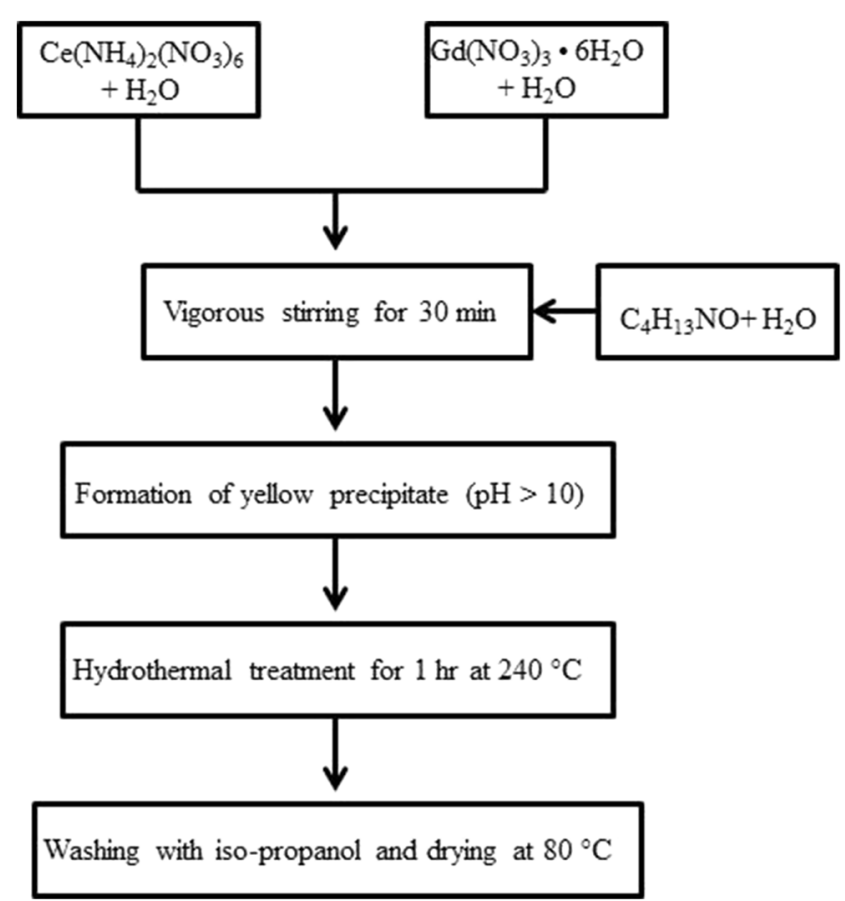

Fig. 1 Synthesis of $\mathrm{CeO}_{2}$ nanoparticles by a hydrothermal method 
pressure without stirring to obtain cerium (or Gd-doped cerium) oxide. The clear supernatant was decanted, and the yellowish precipitate was washed with isopropanol and then dried at $80-85{ }^{\circ} \mathrm{C}$ overnight.

An X'PERT PRO Panalytical X-ray diffractometer (Westborough, MA) was used to determine the phase of the prepared ceria powders using $\mathrm{Cu} \mathrm{K} \alpha$ radiation. Data was collected from $10^{\circ}-90^{\circ}$ angles $(2 \theta)$ with a step size of 0.02 increments at a rate of $1 \% \mathrm{~min}$. Phase identification was achieved by X'PERT PRO software through the comparison of indexed powder diffraction files maintained by International Center for Diffraction Data. The morphology of the synthesized ceria powders was examined by scanning electron microscopy (SEM; JEOL 7600F; Peabody, MA). Energy-dispersive $\mathrm{X}$-ray spectroscopy (EDS) was used to identify the elemental composition of the prepared powders. The X-ray photoelectron spectroscopy (XPS) measurements were carried out using a Physical Electronics, PHI 5000 Versa Probe (XPS/UPS) spectrometer (Chanhassen, MN) with a monochromatic $\mathrm{Al} \mathrm{K} \alpha$ source operated at $300 \mathrm{~W}$ and a base pressure of $5 \times 10^{-8}$ Torr. XPS is a surface-sensitive technique that analyzes the top 25 to 50 angstroms of a particles exterior. The spectrometer was configured to operate at high resolution with energy of $100 \mathrm{eV}$. The acquisition time of the sample was kept low to minimize surface oxidation state changes during X-ray irradiation. The XPS analysis was performed to understand the changes in the valence state and binding energy of the constituent elements on powder surfaces. The work function of the instrument was calibrated to a binding energy of $83.96 \mathrm{eV}$ for the $\mathrm{Au} 4 \mathrm{f} 7 / 2$ line for metallic gold, and the dispersion of the spectrometer was adjusted to a binding energy of $932.62 \mathrm{eV}$. The powder samples were placed on the sample holder using a double-sided conductive tape followed by 6-h evacuation prior to analyses. Survey spectra were collected by $1.0-\mathrm{eV}$ steps at analyzer pass energy of $160 \mathrm{eV}$ and the high-resolution analysis of small spectrum regions by $0.05-\mathrm{eV}$ steps and pass energy of $20 \mathrm{eV}$. The integrated area under the curve of each de-convoluted peak was used to calculate the concentration of $\mathrm{Ce}^{3+}$ ions as $[C e]=\frac{\left[A v_{0}+A v^{\prime}+A u_{0}+A u^{\prime}\right]}{\sum A_{i}}$ where $A_{i}$ is the integrated area for peak $i$.

The size distributions of $\mathrm{CeO}_{2}$ and $\mathrm{Gd}$-doped $\mathrm{CeO}_{2}$ nanoparticles in a suspended state were assessed using dynamic light scattering (DLS). DLS analyzes the velocity distribution of suspended particles by detecting fluctuations of scattered light produced by Brownian motion of the particles and provides hydrodynamic radius or diameter of the particles. All measurements were performed using a Nano ZS90 instrument (Malvern Instruments; Worcestershire, UK). Prior to measurement, each sample cell was cleaned, rinsed with $0.02-\mu \mathrm{m}$ filtered water, and pre-wetted with dispersion media (DM). Suspensions of each material in DM were subjected to ultrasonic agitation using a probe tip for 10 to $20 \mathrm{~min}$ (delivered energy $=4500$ to $9000 \mathrm{~J}$ ) until a uniform dispersion appeared. An ice bath was used to cool the samples during sonication.

The zeta potentials of $\mathrm{CeO}_{2}$ and $\mathrm{Gd}$-doped $\mathrm{CeO}_{2}$ nanoparticles in a suspended state were assessed to describe the stability of the dispersions in DM. All measurements were performed using a Nano ZS90 instrument (Malvern Instruments; Worcestershire, UK). Prior to measurement, each sample cell was cleaned and rinsed with $0.02-\mu \mathrm{m}$ filtered water and ethanol. All dispersant media were filtered through a $0.02-\mu \mathrm{m}$ membrane prior to use as well. The viscosity of the dispersant was determined at room temperature using a VS-10 viscometer (Malvern Instruments), and measured values were used in the calculation of zeta potential. Each nanoparticle suspension was subjected to ultrasonic agitation for up to $10 \mathrm{~min}$ using a probe tip (delivered energy $=4400 \mathrm{~J}$ ). The Smoluchowski approximation of 1.5 was used for Henry's function, and a $\mathrm{pH}$ of 7.51 was determined for the DM.

Nitrogen gas adsorption was used to determine powderspecific surface area (SSA) using a multipoint Brunauer, Emmett, and Teller (BET) instrument (ASAP2020 surface area analyzer; Micromeritics; Norcross, GA). Prior to analysis, powders were outgassed under vacuum ( 0.013 Torr) for $3 \mathrm{~h}$ at $150{ }^{\circ} \mathrm{C}$ to remove moisture [14]. The transmission electron microscopy (TEM) samples were prepared by sonicating a mixture of $\mathrm{CeO}_{2}$ nanopowder and $\mathrm{DM}$ for 2 min to disperse the nanoparticles. Ethanol was added and the solution was sonicated for an additional $5 \mathrm{~min}$. One drop of the resulting solution was placed on a carbon-coated copper TEM grid for imaging on a JEOL JEM 2100 (Peabody, MA) TEM with $\mathrm{LaB}_{6}$ filament operated at $200 \mathrm{kV}$. Regular micrographs were taken with a Gatan ES500W (Gatan; Pleasanton, CA) digital camera, and high-resolution images were obtained with an Orius SC1000 (Gatan; Pleasanton, CA) camera.

\section{Determination of Cellular Interaction}

To visualize nanoparticles, which are not visible using typical light microscopy, enhanced darkfield microscopy was employed [15]. RLE-6TN and NR8383 cells were grown on cleaned, autoclaved cover-glass (Chemglass Life Sciences; Vineland, NJ) until 60-80\% confluent. $\mathrm{CeO}_{2}$, Gd-doped $\mathrm{CeO}_{2}$, and $\mathrm{Gd}_{2} \mathrm{O}_{3}$ nanoparticles were prepared in $\mathrm{DM}$ at a stock concentration of $1 \mathrm{mg} / \mathrm{ml}$, as previously described [16]. Cells were then treated with $\mathrm{CeO}_{2}$ or $\mathrm{Gd}_{2} \mathrm{O}_{3}$ (SigmaAldrich; St. Louis, $\mathrm{MO}$ ) nanoparticles at a final concentration of $10 \mu \mathrm{g} / \mathrm{ml}$ for $5 \mathrm{~min}, 1 \mathrm{~h}$, and $3 \mathrm{~h}$. Following incubation, the medium was removed and the cells were washed three times with warm phosphate-buffered saline (PBS), fixed with $10 \%$ formalin for $10 \mathrm{~min}$, washed three times with PBS, mounted 
with Fluoromount G (eBioscience; San Diego, CA), and sealed with clear nail polish. Slides used for this experiment were purchased as clean cut slides to avoid silica particle residue, which results in high background during imaging (Schott Nexterion, Arlington, VA). Following mounting, images were acquired at 60x magnification using a Cytoviva enhanced darkfield microscopy system (Aetos Technologies; Inc., Auburn, AL) integrated into an Olympus BX41 upright optical microscope equipped with an Olympus DP73 digital camera (Olympus; Center Valley, PA).

\section{Electron Paramagnetic Resonance (EPR)}

A spin trap technique was used to form long-lived free radicals that could be detected by EPR through addition of 5-(diethioxyphosphoyl)-5-methyl-1-pyrroline $N$-oxide (DEPMPO) or 5,5'-dimethylpyrroline $N$-oxide (DMPO). EPR measurements were collected using a flat cell assembly and Brüker EMX spectrometer (Billerica, MA). $\mathrm{CeO}_{2}$ and Gddoped $\mathrm{CeO}_{2}$ nanoparticles were incubated at a final concentration of $1 \mathrm{mg} / \mathrm{ml}$ with $50 \mathrm{mM}$ DEPMPO (Cayman Chemical, Ann Arbor, Michigan), $3.5 \mathrm{mM}$ xanthine, and $2 \mathrm{U} / \mathrm{ml}$ xanthine oxidase (Sigma-Aldrich) for $3 \mathrm{~min}$ to produce superoxide radicals. To induce hydroxyl radicals in an acellular system and assess antioxidant potential, $\mathrm{CeO}_{2}$ and Gd-doped $\mathrm{CeO}_{2}$ were incubated at a final concentration of $1 \mathrm{mg} / \mathrm{ml}$ with $100 \mathrm{mM}$ DMPO (Sigma-Aldrich) and $1 \mathrm{mM}$ $\mathrm{H}_{2} \mathrm{O}_{2}$ and then exposed to UV light for $1 \mathrm{~min}$. The mass of $\mathrm{Gd}_{2} \mathrm{O}_{3}$ powder was adjusted to achieve a final concentration of $179 \mu \mathrm{g} / \mathrm{ml}$, as this value represents the theoretical amount of elemental $\mathrm{Gd}$ in the $20 \mathrm{~mol} \% \mathrm{Gd}$-doped $\mathrm{CeO}_{2}$ nanoparticles. This reaction was also run in the absence of UV light to assess the ability of $\mathrm{CeO}_{2}$ and $\mathrm{Gd}$-doped $\mathrm{CeO}_{2}$ to produce hydroxyl radicals. Samples were run in triplicate, and instrument settings are indicated under "Results." Signal intensity (peak height) was used to measure the relative amount of superoxide radicals produced and is measured in millimeters.

For cellular EPR, $\mathrm{CeO}_{2}$ and Gd-doped $\mathrm{CeO}_{2}$ at final concentrations of $1 \mathrm{mg} / \mathrm{ml}$ or $\mathrm{Gd}_{2} \mathrm{O}_{3}$ at $179 \mu \mathrm{g} / \mathrm{ml}$ were incubated with either RLE-6TN or NR8383 cells at $2 \times 10^{6}$ cells $/ \mathrm{ml}$ and $200 \mathrm{mM}$ DMPO for $3 \mathrm{~min}$ at $37^{\circ} \mathrm{C}[17,18]$. Reactions were run in triplicate. This reaction was repeated but $2 \mathrm{mM} \mathrm{Cr}(\mathrm{VI})$ was added to the system to induce hydroxyl radicals. Peak heights represent relative amounts of hydroxyl radicals produced and are measured in millimeters.

\section{Annexin V/Propidium Iodide}

The degree of apoptosis and necrosis induced by $\mathrm{CeO}_{2}$ and Gd-doped $\mathrm{CeO}_{2}$ at $24 \mathrm{~h}$ was determined by flow cytometry. RLE-6TN cells were seeded at $1 \times 10^{5}$ cells per well in 24 -well plates, and NR8383 cells were seeded at $3 \times 10^{5}$ cells per well. Following $24 \mathrm{~h}$ of growth, cells were treated with $\mathrm{CeO}_{2}$ and Gd-doped $\mathrm{CeO}_{2}$ at a final concentration of 10 or $50 \mu \mathrm{g} / \mathrm{ml}$ for $24 \mathrm{~h}$ or treated with $\mathrm{Gd}_{2} \mathrm{O}_{3}$ at a final concentration of 1.79 or $8.95 \mu \mathrm{g} / \mathrm{ml}$. The annexin $\mathrm{V} /$ propidium iodide assay was completed according to company protocol (Trevigen; Gaithersburg, MD). Briefly, cell media were collected followed by trypsinization of cells for $2 \mathrm{~min}$. Trypsinized cells were combined with media to ensure collection of viable, apoptotic, and necrotic cells. Following a washing step, cells were incubated for 15 min with $100 \mu \mathrm{l}$ annexin V/propidium iodide stain then analyzed on a BD Biosciences LSR II flow cytometer. All data were analyzed using DIVA software and 10,000 events per sample were collected. Samples were run three times in duplicate and are presented in graphical rather than scatter plot format.

\section{Statistical Analysis}

All data are represented as the mean \pm standard deviation for each condition. To compare responses between groups, a oneway analysis of variance (ANOVA) and Tukey posttest were performed using GraphPad Prism 6 software (GraphPad Software, Inc.; La Jolla, CA). Statistical significance is shown when $p<0.05$.

\section{Results}

\section{$\mathrm{CeO}_{2}$ Characteristics}

The XRD diffraction peaks of the $\mathrm{CeO}_{2}$, which represent the crystalline plane (1 111 ), (2 $\left.\begin{array}{lll}2 & 0\end{array}\right),\left(\begin{array}{lll}2 & 2 & 0\end{array}\right)$, and ( $\left.\begin{array}{lll}3 & 1 & 1\end{array}\right)$, correspond to cubic fluorite crystal structure (JCPDS Data Card \# 88-2326), where $\mathrm{Ce}$ is in the 4+ oxidation state [19]. The XRD pattern of $\mathrm{CeO}_{2} 10 \% \mathrm{Gd}$ and $\mathrm{CeO}_{2} 20 \% \mathrm{Gd}$ showed no $\mathrm{Gd}$ oxide peaks, indicating the formation of $\mathrm{Gd}-\mathrm{CeO}_{2}$ solid solution [19] (data not shown). SEM was used to assess the agglomeration of the nanoparticles (Online Resource 1) and indicated that the $\mathrm{CeO}_{2}$ and doped- $\mathrm{CeO}_{2}$ powders agglomerated and that there was a wide distribution of particle sizes. The EDS pattern of pure $\mathrm{CeO}_{2}$ (data not shown) did not reveal any impurities present in the powder.

Figure 2a shows the wide scan XPS survey spectra for pure $\mathrm{CeO}_{2}, \mathrm{CeO}_{2} 10 \% \mathrm{Gd}$, and $\mathrm{CeO}_{2} 20 \% \mathrm{Gd}$. High-resolution XPS spectra for $\mathrm{Ce}(3 \mathrm{~d})$, the fitted curve, and the corresponding de-convoluted peaks of $\mathrm{CeO}_{2}$ nanoparticles are shown in Fig. 2b. The recorded XPS spectra were charge corrected with respect to the $\mathrm{C}(1 \mathrm{~s})$ peak at $284.6 \mathrm{eV}$. The peaks in the spectrum of Ce were de-convoluted using the multi-pack software. The letter "v" marked in the spectra indicates the spin-orbit coupling $3 d_{5 / 2}$, and the letter " $u$ " indicates spin orbit coupling 

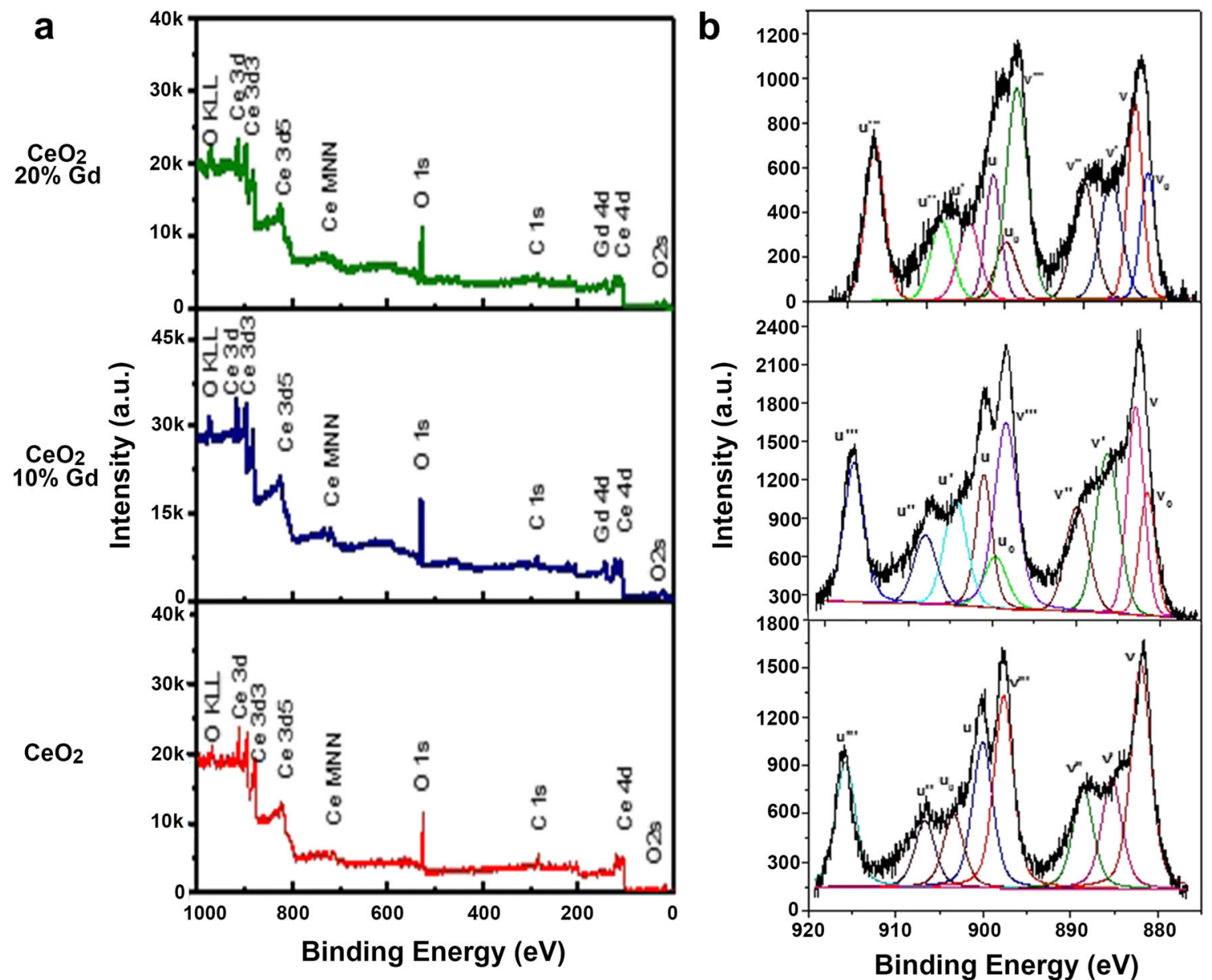

Fig. 2 XPS survey of $\mathrm{CeO}_{2}$ nanoparticles. a Wide-scan XPS survey scan spectrum of $\mathrm{CeO}_{2} 20 \% \mathrm{Gd}_{2} \mathrm{CeO}_{2} 10 \% \mathrm{Gd}$, and pure $\mathrm{CeO}_{2}$. b $\mathrm{High}$-resolution XPS spectrum of $\mathrm{CeO}_{2} 20 \% \mathrm{Gd}, \mathrm{CeO}_{2} 10 \% \mathrm{Gd}$, and pure $\mathrm{CeO}_{2}$

Table 1 XPS analysis of $\mathrm{Ce}^{3+}$ and $\mathrm{Ce}^{4+}$ ion concentration

\begin{tabular}{|c|c|c|c|c|c|c|c|}
\hline Samples & $\begin{array}{l}\text { Binding } \\
\text { energy }(\mathrm{eV})\end{array}$ & Peak height & Peak area & & {$\left[\mathrm{Ce}^{4+}\right]$} & {$\left[\mathrm{Ce}^{3+}\right]$} & $\mathrm{Ce}^{3+} / \mathrm{Ce}^{4+}$ \\
\hline \multirow[t]{5}{*}{$\mathrm{CeO}_{2}$} & 881.96 & 1382 & 4717 & $\mathrm{Ce}^{4+}$ & 13,981 & 2363 & 0.169 \\
\hline & 885.3 & 683 & 2363 & $\mathrm{Ce}^{3+}$ & & & \\
\hline & 888.57 & 625 & 2166 & $\mathrm{Ce}^{4+}$ & & & \\
\hline & 897.66 & 1184 & 3985 & $\mathrm{Ce}^{4+}$ & & & \\
\hline & 900.06 & 899 & 3113 & $\mathrm{Ce}^{4+}$ & & & \\
\hline \multirow[t]{5}{*}{$\mathrm{CeO}_{2} 10 \% \mathrm{Gd}$} & 881.49 & 781 & 1944 & $\mathrm{Ce}^{3+}$ & 13,790 & 5892 & 0.427 \\
\hline & 883.02 & 1512 & 4306 & $\mathrm{Ce}^{4+}$ & & & \\
\hline & 886.13 & 1096 & 3948 & $\mathrm{Ce}^{3+}$ & & & \\
\hline & 889.55 & 838 & 3134 & $\mathrm{Ce}^{4+}$ & & & \\
\hline & 898.42 & 1616 & 6350 & $\mathrm{Ce}^{4+}$ & & & \\
\hline \multirow[t]{5}{*}{$\mathrm{CeO}_{2} 20 \% \mathrm{Gd}$} & 881.6 & 563 & 1401 & $\mathrm{Ce}^{3+}$ & 7525 & 3301 & 0.439 \\
\hline & 883.33 & 876 & 2181 & $\mathrm{Ce}^{4+}$ & & & \\
\hline & 886.42 & 527 & 1900 & $\mathrm{Ce}^{3+}$ & & & \\
\hline & 889.92 & 538 & 1938 & $\mathrm{Ce}^{4+}$ & & & \\
\hline & 898.4 & 946 & 3406 & $\mathrm{Ce}^{4+}$ & & & \\
\hline
\end{tabular}


$3 \mathrm{~d}_{3 / 2}$ of pure $\mathrm{CeO}_{2}$. The peaks denoted by $v_{0}, v^{\prime}, u_{0}$, and $u^{\prime}$ represent $\mathrm{Ce}^{3+}$ ions, whereas those marked by $v, v^{\prime \prime}, v^{\prime \prime \prime}, u, u^{\prime \prime}$, and $u^{\prime \prime \prime}$ represent $\mathrm{Ce}^{4+}$ ions. It is evident that the deconvoluted $\mathrm{Ce}(3 \mathrm{~d})$ spectrum is relatively complex due to the presence of $\mathrm{Ce}$ in $3+$ and $4+$ oxidation states as well as multiple d-splitting. The spin orbit doublets for pure $\mathrm{CeO}_{2}$, $3 \mathrm{~d}_{3 / 2}(885.3$ and $903.4 \mathrm{eV})$, and $3 \mathrm{~d}_{5 / 2}(881.9$ and $888.6 \mathrm{eV})$ are clearly evident for both valence states of $\mathrm{Ce}$, indicating that $\mathrm{Ce}$ is in mixed valence states of $3+$ and $4+$ [20]. Highresolution XPS spectra for $\mathrm{Ce}(3 \mathrm{~d})$, the fitted curve, and the corresponding de-convoluted peaks of pure $\mathrm{CeO}_{2}, \mathrm{CeO}_{2} 10 \%$ $\mathrm{Gd}$, and $\mathrm{CeO}_{2} 20 \% \mathrm{Gd}$ are presented in Fig. 2. Table 1 shows the binding energies, peak heights, peak areas, and the concentrations of $\mathrm{Ce}^{3+}$ and $\mathrm{Ce}^{4+}$ atoms of pure $\mathrm{CeO}_{2}, \mathrm{CeO}_{2} 10 \%$ $\mathrm{Gd}$, and $\mathrm{CeO}_{2} 20 \% \mathrm{Gd}$. The characteristic peaks of $\mathrm{Gd}^{3+} 3 \mathrm{~d}_{5 / 2}$ were observed in the region $1183.83 \pm 0.7$ and $1215.83 \pm$ $0.7 \mathrm{eV}$ in $\mathrm{CeO}_{2} 10 \% \mathrm{Gd}$ and $1187.07 \pm 0.7$ and $1219.07 \pm$ $0.7 \mathrm{eV}$ in $\mathrm{CeO}_{2} 20 \% \mathrm{Gd}$, indicating that $\mathrm{Gd}$ is in the $3+$ oxidation state (Fig. 2). It was observed that in both the peaks of $\mathrm{Gd}^{3+}$, there was a slight shift toward the lower binding energy, which can be attributed to the increase in valence electron density. From the table, it may be seen that the addition of $\mathrm{Gd}$ increases the $\mathrm{Ce}^{3+}$ state. The ratios of $\mathrm{Ce}^{3+} / \mathrm{Ce}^{4+}$ were found to be $16.9,42.7$, and $43.9 \%$ for pure $\mathrm{CeO}_{2}, \mathrm{CeO}_{2}$ $10 \% \mathrm{Gd}$, and $\mathrm{CeO}_{2} 20 \% \mathrm{Gd}$, respectively. The high value of $v_{0} / u_{0}$ and $v^{\prime} / u^{\prime}$ indicates that nanosized ceria exhibits better catalytic activity due to the large amount of electronic and ionic defects, which include the presence of $\mathrm{Ce}^{3+}$ and $\mathrm{Gd}^{3+}$ atoms and the corresponding oxygen vacancies $\left(V_{\mathrm{O}}{ }^{\prime \prime}\right)$. Gd is a lanthanide that can be used to modify the chemical, crystal structure, and defect state of ceria. The atomic radius and the electron negativity of $\mathrm{Gd}$ are close to that of the cerium atom, so the atom fits into the $\mathrm{Ce}$-site within the fluorite structure. It must be noted that, as the amount of $\mathrm{Ce}^{3+}$ and $\mathrm{Gd}^{3+}$ states within the structure increases, the structure must compensate for these additions by increasing the positive charge within the material to retain charge neutrality. The material typically compensates for this ionic defect by releasing oxygen from the structure, resulting in an open anionic site within the structure (oxygen vacancy, $\mathrm{V}_{\mathrm{O}}{ }^{\prime \prime}$ ). The oxygen vacancies may be considered as open sites within the bulk and surface structure for the uptake of oxygen and are critical for the efficient diffusion of oxygen ions within or on the surface of the ceria.

Hydrodynamic diameter and zeta potential were measured to assess particle agglomeration under physiological exposure conditions, while TEM was used to observe particle size. The results indicated that the hydrodynamic diameters of all three $\mathrm{CeO}_{2}$ nanoparticles $\left(\mathrm{CeO}_{2}, 875 \pm 58 ; \mathrm{CeO}_{2} 10 \% \mathrm{Gd}, 201 \pm 5\right.$; $\mathrm{CeO}_{2} 20 \% \mathrm{Gd}, 176 \pm 8$ ) (Table 2) were larger than the observed size under TEM ( $\sim 5 \mathrm{~nm}$ ) (Online Resource 2$)$. The zeta potential indicates that the nanoparticle dispersions are likely to agglomerate in DM (Table 2) based on the stability
Table 2 Characteristics of pure and doped $\mathrm{CeO}_{2}$ nanoparticles

\begin{tabular}{llll}
\hline Nanoparticle & $\begin{array}{l}\text { Hydrodynamic } \\
\text { diameter }(\mathrm{nm})\end{array}$ & Zeta potential & $\begin{array}{l}\text { Surface area } \\
(\mathrm{CV} \%)\end{array}$ \\
\hline $\mathrm{CeO}_{2}$ & $875 \pm 58$ & $-10.6 \pm 2.4$ & $204.8 \pm 14.6(7.1)$ \\
$\mathrm{CeO}_{2} 10 \% \mathrm{Gd}$ & $201 \pm 5$ & $-16.3 \pm 2.6$ & $225.4 \pm 34.1(15.1)$ \\
$\mathrm{CeO}_{2} 20 \% \mathrm{Gd}$ & $176 \pm 8$ & $-12.8 \pm 1.6$ & $135.6 \pm 5.6(4.1)$ \\
\hline
\end{tabular}

categories developed by Riddick [21]. Thus, the results show that the stability of the nanoparticle dispersions is fairly poor overtime. The surface area results implicate that the pure $\mathrm{CeO}_{2}$ and $\mathrm{CeO}_{2} 10 \% \mathrm{Gd}$ were of similar surface area, while the surface area of $\mathrm{CeO}_{2} 20 \% \mathrm{Gd}$ was substantially less (Table 2).

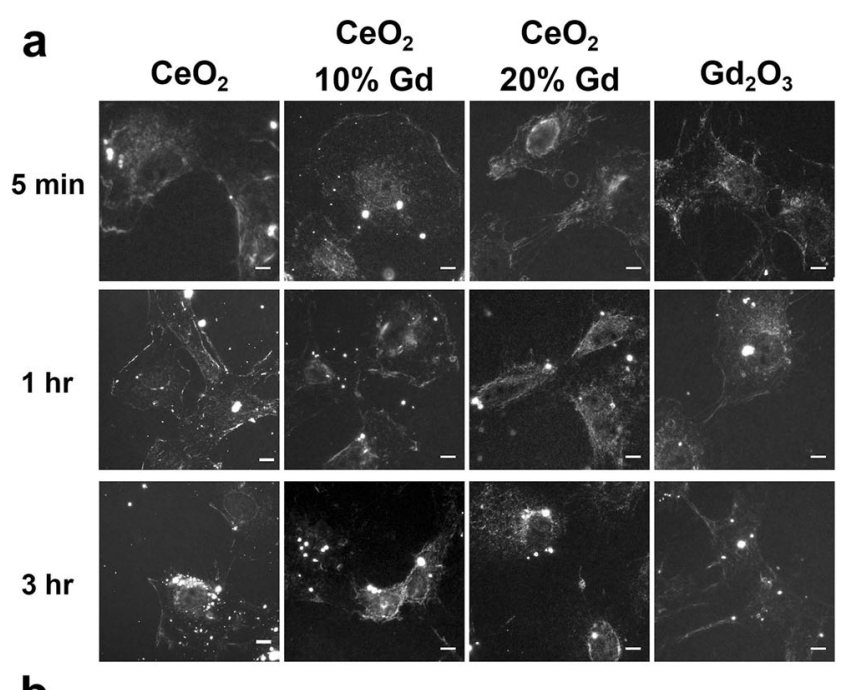

b

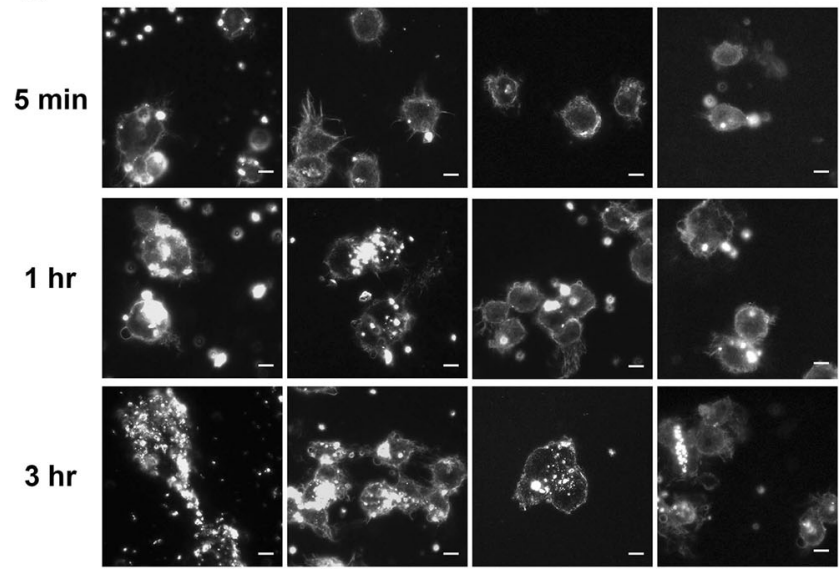

Fig. 3 Epithelial and macrophage cells associate with $\mathrm{CeO}_{2}$ nanoparticles over a time course. a Cytoviva-enhanced dark-field microscopy system provides images of high-contrast $\mathrm{CeO}_{2}$ nanoparticles (bright spots) against a dark background of cells. Cells were exposed to $\mathrm{CeO}_{2}$ nanoparticles for $5 \mathrm{~min}, 1 \mathrm{~h}$, or $3 \mathrm{~h}$. a Representative images of RLE-6TN cells associated with $\mathrm{CeO}_{2}$ nanoparticles. b As in a, except images are representative of NR8383 cells. Scale bar, $5 \mu \mathrm{m}$ 
Cellular Interactions with Particles Show Accumulation Over Time

Enhanced darkfield microscopy was used to visualize $\mathrm{CeO}_{2}$ and $\mathrm{Gd}_{2} \mathrm{O}_{3}$ nanoparticle cellular interactions over a time course of $3 \mathrm{~h}$. The results demonstrated that all $\mathrm{CeO}_{2}$ nanoparticles and $\mathrm{Gd}_{2} \mathrm{O}_{3}$ accumulated with cells over time (Fig. 3). Figure $3 \mathrm{~b}$ illustrates that all nanoparticles associated with NR8383 cells more rapidly than RLE-6TN cells.

\section{Super Oxide Radical Scavenging with $\mathrm{CeO}_{2}$ Nanoparticles}

Studies have indicated that $\mathrm{CeO}_{2}$ has superoxide dismutase properties [11]; thus, the effect of doping and alteration in valence state on superoxide scavenging was assessed using a xanthine oxidase/xanthine reaction and spin trap technique. Results showed that all three $\mathrm{CeO}_{2}$ nanoparticles had significant scavenging properties in a 3-min acellular system; however, the $\mathrm{Gd}_{2} \mathrm{O}_{3}$ positive control did not have this effect (Fig. 4).

\section{Hydroxyl Radical Scavenging with $\mathrm{CeO}_{2}$ Nanoparticles}

As a result of the rapid association of nanoparticles with cells (within $5 \mathrm{~min}$ ) and previous studies implicating that $\mathrm{CeO}_{2}$ can induce or scavenge $\operatorname{ROS}[7,11,22]$, hydroxyl radical production was measured. To determine whether $\mathrm{CeO}_{2}$ and $\mathrm{Gd}_{2} \mathrm{O}_{3}$ nanoparticles are capable of converting $\mathrm{H}_{2} \mathrm{O}_{2}$ into hydroxyl radicals, acellular Fenton-like reactions were carried out using EPR and a spin trap method. Neither $\mathrm{CeO}_{2}$ (pure and doped) nor $\mathrm{Gd}_{2} \mathrm{O}_{3}$ induced hydroxyl radicals in an acellular system (data not shown). Further, because previous studies have shown that $\mathrm{CeO}_{2}$ has scavenging abilities [8], the ability of $\mathrm{CeO}_{2}$ to scavenge hydroxyl radicals was carried out using $\mathrm{H}_{2} \mathrm{O}_{2}$, UV light, and a spin trap method. Results indicated that pure $\mathrm{CeO}_{2}, \mathrm{CeO}_{2} 10 \% \mathrm{Gd}$, and $\mathrm{CeO}_{2} 20 \% \mathrm{Gd}$ had significant antioxidant effects, while $\mathrm{Gd}_{2} \mathrm{O}_{3}$ had no significant effects on induced hydroxyl radicals within $3 \mathrm{~min}$ in an acellular system (Fig. 5).

While all three $\mathrm{CeO}_{2}$ nanoparticles did not generate hydroxyl radicals in an acellular system, previous studies have shown that $\mathrm{CeO}_{2}$ induces significant ROS in vitro [6, 7]; thus, cellular EPR was completed. The results showed that in RLE$6 \mathrm{TN}$ cells, all three $\mathrm{CeO}_{2}$ nanoparticles significantly reduced the presence of hydroxyl radicals; however, in NR8383 cells, only pure $\mathrm{CeO}_{2}$ and $\mathrm{CeO}_{2} 10 \% \mathrm{Gd}$ significantly scavenged the free radicals. In both cell lines, the $\mathrm{Gd}_{2} \mathrm{O}_{3}$ control had no effect (Figs. 6 and 7).

\section{$\mathrm{CeO}_{2}$ Nanoparticle Exposure Effects on Cell Viability}

To measure $\mathrm{CeO}_{2}$ effects on apoptosis and necrosis at $24 \mathrm{~h}$, an annexin $\mathrm{V} /$ propidium iodide dual stain was used. At $24 \mathrm{~h}$, no $\mathrm{CeO}_{2}$ nanoparticle affected overall cell viability in RLE-6TN cells at either 10 or $50 \mu \mathrm{g} / \mathrm{ml}$ doses. $\mathrm{Gd}_{2} \mathrm{O}_{3}$ induced significant apoptosis (annexin $\mathrm{V}$ positive) at $8.95 \mu \mathrm{g} / \mathrm{ml}$ compared to the control (Fig. 8).

In NR8383 cells, pure $\mathrm{CeO}_{2}$, doped $\mathrm{CeO}_{2}$, and $\mathrm{Gd}_{2} \mathrm{O}_{3}$ nanoparticles had no significant effects on overall cell viability or development of necrosis. However, $\mathrm{Gd}_{2} \mathrm{O}_{3}$

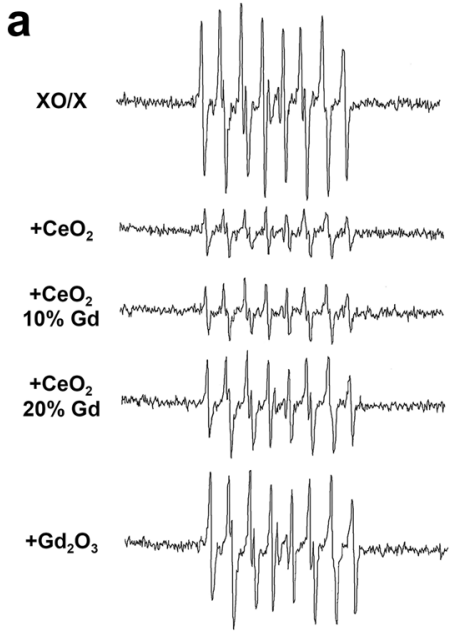

Fig. $4 \mathrm{CeO}_{2}$ nanoparticles reduce superoxide radicals. a $\mathrm{CeO}_{2}$ nanoparticles at $1 \mathrm{mg} / \mathrm{ml}\left(\mathrm{Gd}_{2} \mathrm{O}_{3}\right.$ at $\left.179 \mu \mathrm{g} / \mathrm{ml}\right)$ were combined with $50 \mathrm{mM}$ DEPMPO, $3.5 \mathrm{mM}$ xanthine, and $2 \mathrm{U} / \mathrm{ml}$ xanthine oxidase (XO/X) for $3 \mathrm{~min}$. EPR setting were the following: center field, $3490 \mathrm{G}$; scan width, $200 \mathrm{G}$; time constant, $0.41 \mathrm{~s}$; modulation amplitude, $1 \mathrm{G}$; receiver gain, $2.5 \times 10^{4}$; frequency, $9.8 \mathrm{GHz}$; and

b

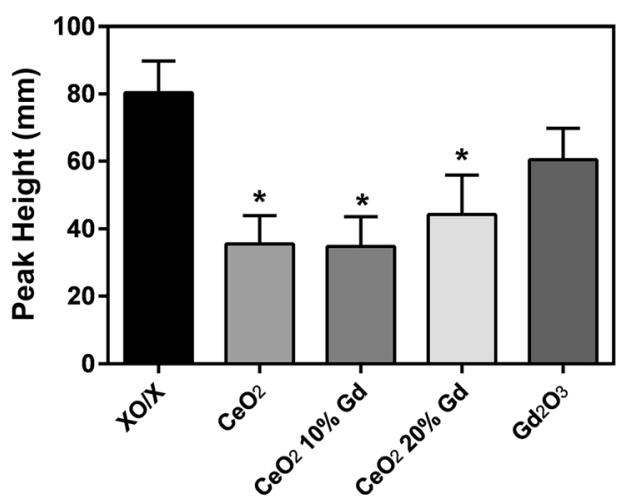

power, $63 \mathrm{~mW}$. Representative spectra for each sample are shown. b The first, fourth, fifth, and eighth peaks were used for measurement of superoxide radical production. Signal intensity was measured in millimeters. Error bars represent the mean \pm standard deviation. ${ }^{*} p<0.05$ compared to $\mathrm{XO} / \mathrm{X}$ 


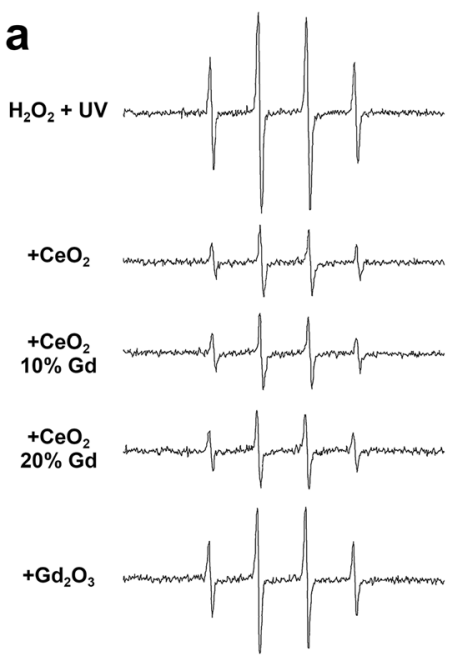

Fig. $5 \mathrm{CeO}_{2}$ nanoparticles reduce hydroxyl radicals. a $\mathrm{CeO}_{2}$ nanoparticles at $1 \mathrm{mg} / \mathrm{ml}\left(\mathrm{Gd}_{2} \mathrm{O}_{3}\right.$ at $\left.179 \mu \mathrm{g} / \mathrm{ml}\right)$ were combined with $100 \mathrm{mM}$ DMPO and $1 \mathrm{mM} \mathrm{H}_{2} \mathrm{O}_{2}$ then exposed to UV light for $1 \mathrm{~min}$. EPR setting were the following: center field, $3487 \mathrm{G}$; scan width, $100 \mathrm{G}$; time constant, $0.41 \mathrm{~s}$; modulation amplitude, $1 \mathrm{G}$; receiver gain, $2.5 \times 10^{4}$;

significantly increased the number of cells undergoing apoptosis at a dose of $8.95 \mu \mathrm{g} / \mathrm{ml}$ compared to the control (Fig. 9).

\section{Discussion}

As industrial interest in the use of $\mathrm{CeO}_{2}$ nanoparticles increases so will manufacturing and worker exposures. While disagreements exist within the literature as to the nature of

b

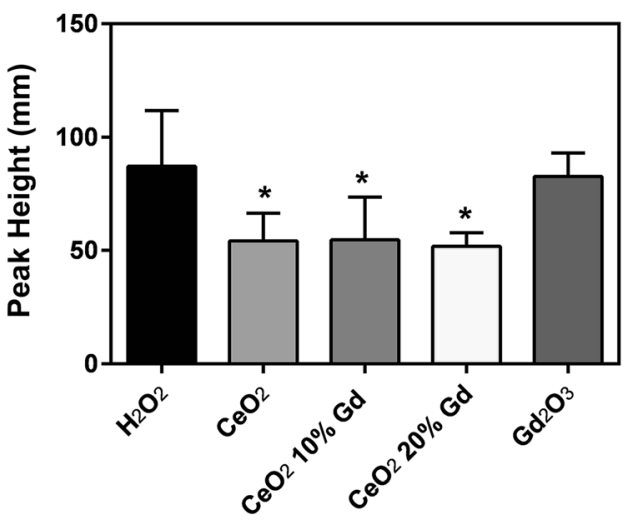

frequency, $9.8 \mathrm{GHz}$; and power, $63 \mathrm{~mW}$. Representative spectra for each sample are shown. b The second and third peaks were used for measurement of hydroxyl radical production. Signal intensity was measured in millimeters. Error bars represent the mean \pm standard deviation. ${ }^{*} p<0.05$ compared to $\mathrm{H}_{2} \mathrm{O}_{2}$

$\mathrm{CeO}_{2}$ toxicity, it is almost universally agreed upon that $\mathrm{CeO}_{2}$ affects ROS, theoretically due to its exceptional redox potential. Therefore, this study focused on examining how altering the valence state of $\mathrm{CeO}_{2}$ nanoparticles through doping affects $\mathrm{CeO}_{2}$ toxicity, specifically its effects on ROS generation.

As predicted, the use of $\mathrm{Gd}_{2} \mathrm{O}_{3}$ as a dopant substantially altered the $\mathrm{Ce}^{3+}$ to $\mathrm{Ce}^{4+}$ ratio of the nanoparticles (Table 1) [4]. XPS analysis of powder surfaces indicated that doping with $\mathrm{Gd}_{2} \mathrm{O}_{3}$ increased the rate of reduction of $\mathrm{Ce}^{4+}$ to $\mathrm{Ce}^{3+}$, a rate

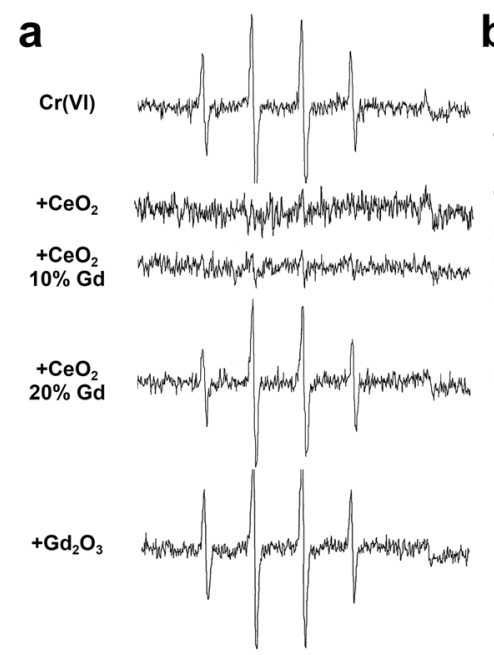

Fig. $6 \mathrm{CeO}_{2}$ nanoparticles reduce induced hydroxyl radicals in RLE6TN cells. a $\mathrm{CeO}_{2}$ nanoparticles at $1 \mathrm{mg} / \mathrm{ml}\left(\mathrm{Gd}_{2} \mathrm{O}_{3}\right.$ at $\left.179 \mu \mathrm{g} / \mathrm{ml}\right)$ were combined with $200 \mathrm{mM}$ DMPO and $2 \times 10^{6}$ cells $/ \mathrm{ml}$ then incubated for $3 \mathrm{~min}$ at $37{ }^{\circ} \mathrm{C}$. EPR setting were the following: center field, $3495 \mathrm{G}$; scan width, $100 \mathrm{G}$; time constant, $0.41 \mathrm{~s}$; modulation amplitude, $1 \mathrm{G}$; receiver gain, $6.3 \times 10^{2}$; frequency, $9.8 \mathrm{GHz}$; and

b

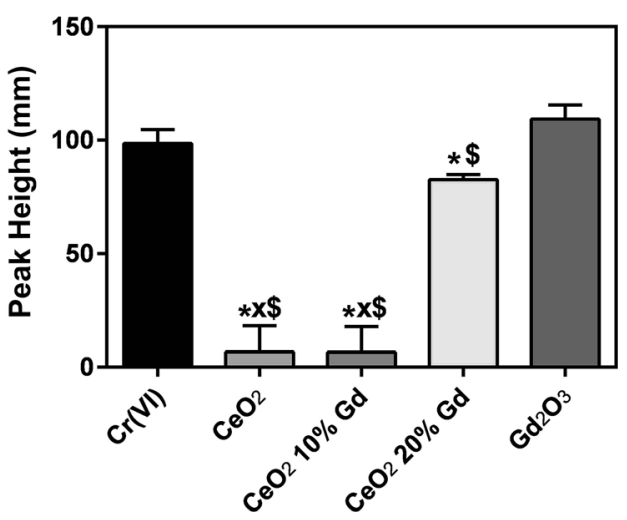

power, $126 \mathrm{~mW}$. Representative spectra for each sample are shown. b The second and third peaks were used for measurement of hydroxyl radical production. Signal intensity was measured in millimeters. Error bars represent the mean \pm standard deviation. ${ }^{*} p<0.05$ compared to control, $x p<0.05$ compared to $\mathrm{CeO}_{2} 20 \% \mathrm{Gd}, \$ p<0.05$ compared to $\mathrm{Gd}_{2} \mathrm{O}_{3}$ 


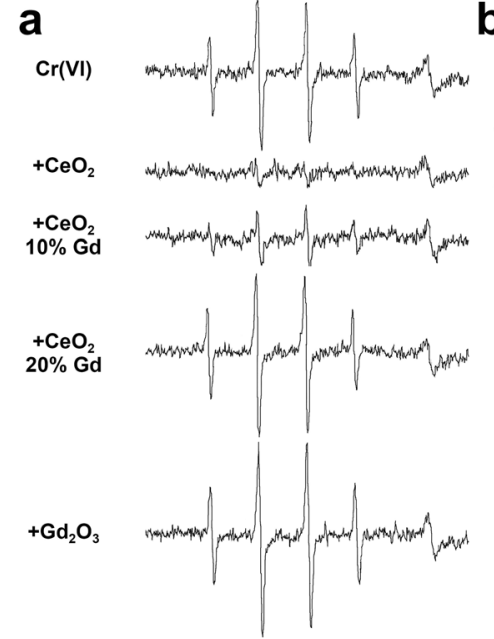

Fig. $7 \mathrm{CeO}_{2}$ nanoparticles reduce induced hydroxyl radicals in NR8383 cells. a $\mathrm{CeO}_{2}$ nanoparticles at $1 \mathrm{mg} / \mathrm{ml}\left(\mathrm{Gd}_{2} \mathrm{O}_{3}\right.$ at $\left.179 \mu \mathrm{g} / \mathrm{ml}\right)$ were combined with $200 \mathrm{mM}$ DMPO and $2 \times 10^{6}$ cells $/ \mathrm{ml}$ then incubated for 3 min at $37^{\circ} \mathrm{C}$. EPR setting were the following: center field, $3495 \mathrm{G}$; scan width, $100 \mathrm{G}$; time constant, $0.41 \mathrm{~s}$; modulation amplitude, $1 \mathrm{G}$; receiver gain, $6.3 \times 10^{2}$; frequency, $9.8 \mathrm{GHz}$; and power, $126 \mathrm{~mW}$. Representative

that increased as the concentration of $\mathrm{Gd}_{2} \mathrm{O}_{3}$ increased. $\mathrm{CeO}_{2}$ containing $10 \mathrm{~mol} \% \mathrm{Gd}_{2} \mathrm{O}_{3}$-doped into the nanoparticles had

\section{a}
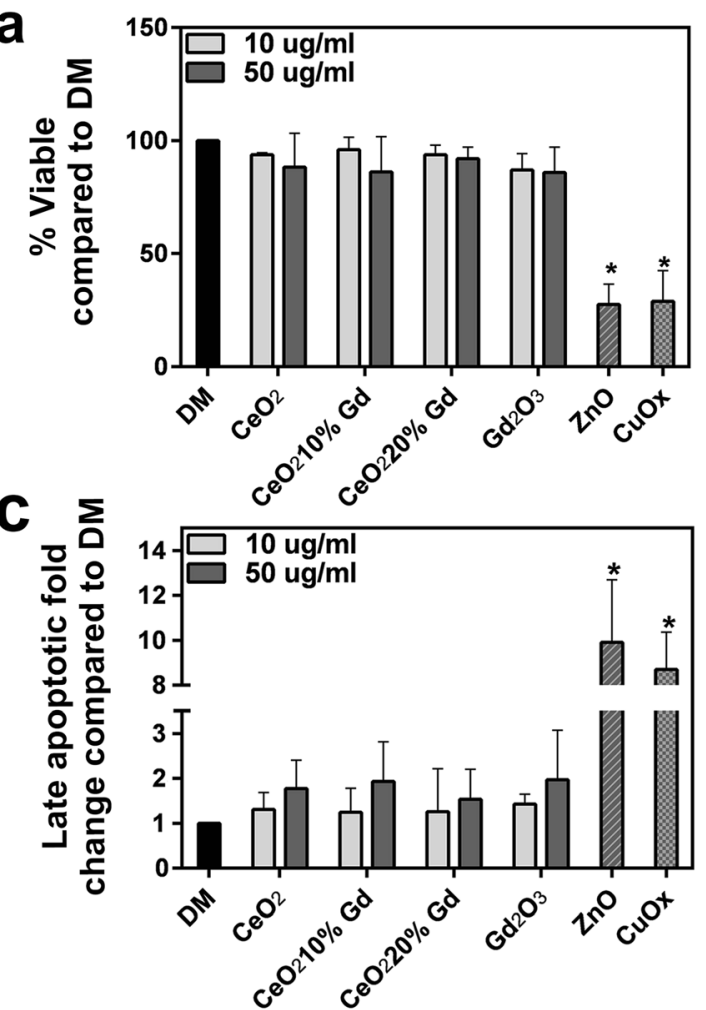

Fig. $8 \mathrm{CeO}_{2}$ nanoparticles cause no significant changes in RLE-6TN cell viability at $24 \mathrm{~h}$. a RLE-6TN cells were exposed to $\mathrm{CeO}_{2}$ at 10 or $50 \mu \mathrm{g} / \mathrm{ml}$ for $24 \mathrm{~h}\left(\mathrm{Gd}_{2} \mathrm{O}_{3}\right.$ at 1.79 or $\left.8.95 \mu \mathrm{g} / \mathrm{ml}\right)$. Collected cells were incubated with annexin V/propidium iodide on ice for $15 \mathrm{~min}$ then run, and 10,000 events were measured. Graph represents cells that were viable after $24 \mathrm{~h}$. $\mathrm{ZnO}$ and $\mathrm{CuOx}$, at $50 \mu \mathrm{g} / \mathrm{ml}$, were used as positive controls for

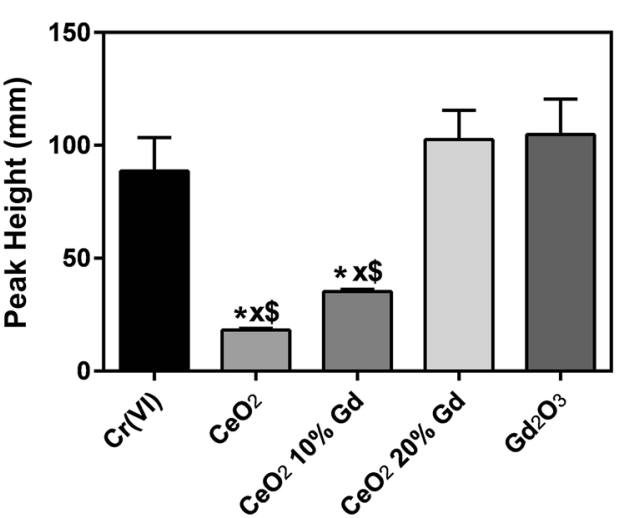

spectra for each sample are shown. b The second and third peaks were used for measurement of hydroxyl radical production. Signal intensity was measured in millimeters. Error bars represent the mean \pm standard deviation. ${ }^{*} p<0.05$ compared to control, $x p<0.05$ compared to $\mathrm{CeO}_{2}$ $20 \% \mathrm{Gd}, \$ p<0.05$ compared to $\mathrm{Gd}_{2} \mathrm{O}_{3}$

a ratio shift from 16 to $42 \%$ compared to pure $\mathrm{CeO}_{2}$, while the $20 \mathrm{~mol} \% \mathrm{Gd}_{2} \mathrm{O}_{3}$-doped nanoparticles shifted the ratio from 16

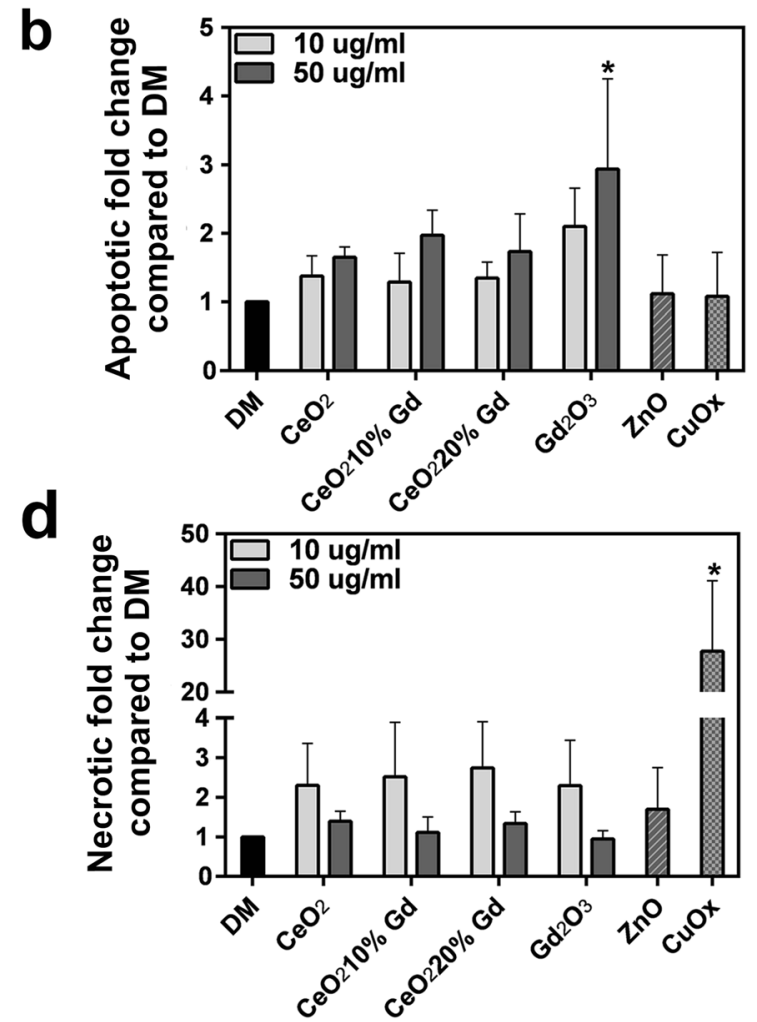

apoptosis and necrosis, respectively, and DM was used as a negative control. Error bars represent mean \pm standard deviation. ${ }^{*} p<0.05$ compared to control. b Cells stained positive for annexin V. c Cells stained positive for both annexin $\mathrm{V}$ and propidium iodide. $\mathbf{d}$ Cells stained positive for propidium iodide 


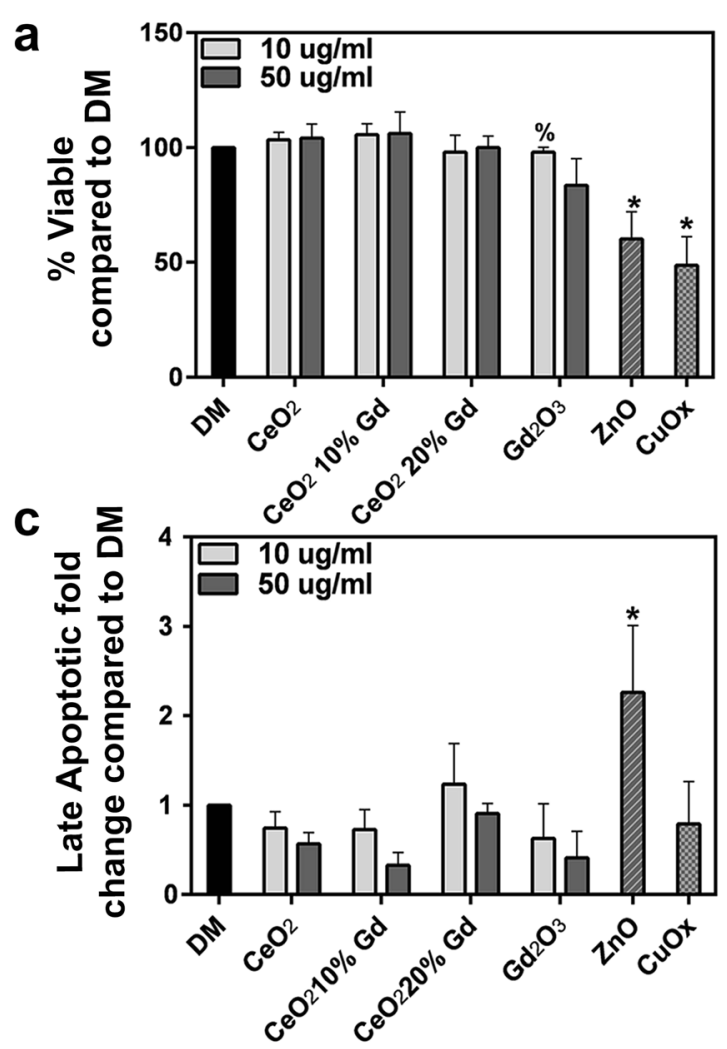

Fig. $9 \mathrm{CeO}_{2}$ nanoparticles cause no significant changes in NR8383 cell viability at $24 \mathrm{~h}$. a NR8383 cells were exposed to $\mathrm{CeO}_{2}$ at 10 or $50 \mu \mathrm{g} / \mathrm{ml}$ for $24 \mathrm{~h}\left(\mathrm{Gd}_{2} \mathrm{O}_{3}\right.$ at 1.79 or $\left.8.95 \mu \mathrm{g} / \mathrm{ml}\right)$. Collected cells were incubated with annexin $\mathrm{V} /$ propidium iodide on ice for $15 \mathrm{~min}$ then run, and 10,000 events were measured. Graph represents cells that were viable after $24 \mathrm{~h}$. $\mathrm{ZnO}$ and $\mathrm{CuOx}$, at $50 \mu \mathrm{g} / \mathrm{ml}$, were used as positive controls for apoptosis

to $44 \%$. Alternatively, a study completed by Celado et al. showed that doping with samarium $(\mathrm{Sm})$ decreased the amount of $\mathrm{Ce}^{3+}$ in the nanoparticles [9]. This difference in doping outcome may be a result of $\mathrm{Gd}_{2} \mathrm{O}_{3}$ to introduce more $\mathrm{Ce}^{3+}$ oxidation state into the nanoparticle compared to $\mathrm{Sm}$ as previously shown [23]. While the effects of doping observed in the two studies conflict, our results correlate with the general finding that as doping increases, antioxidant potential decreases. Thus, in conjunction with the works of Celado et al., it appears that the ratio of $\mathrm{Ce}^{3+} / \mathrm{Ce}^{4+}$ is not as crucial in determining antioxidant potential of $\mathrm{CeO}_{2}$ nanoparticles as is the ability of Ce to transition between the two valence states. This transitional ability is hindered following doping since the Ce nanoparticles are forced toward one valence state and, due to the stability of $\mathrm{Gd}$ in the lattice structure, unable to transition as easily to the other state [4]. Further support of this effect is the mere change in $3+/ 4+$ ratio between the $10 \mathrm{~mol} \% \mathrm{Gd}_{2} \mathrm{O}_{3}$ and $20 \mathrm{~mol} \% \mathrm{Gd}_{2} \mathrm{O}_{3}$-doped $\mathrm{CeO}_{2}$ nanoparticles from 42 to $44 \%$ (Table 1 ) accompanied by the dramatic change in antioxidant potential of the two nanoparticles. This decreased antioxidant effect was most notable in the cellular EPR model, where $\mathrm{CeO}_{2} 20 \% \mathrm{Gd}$ was significantly different

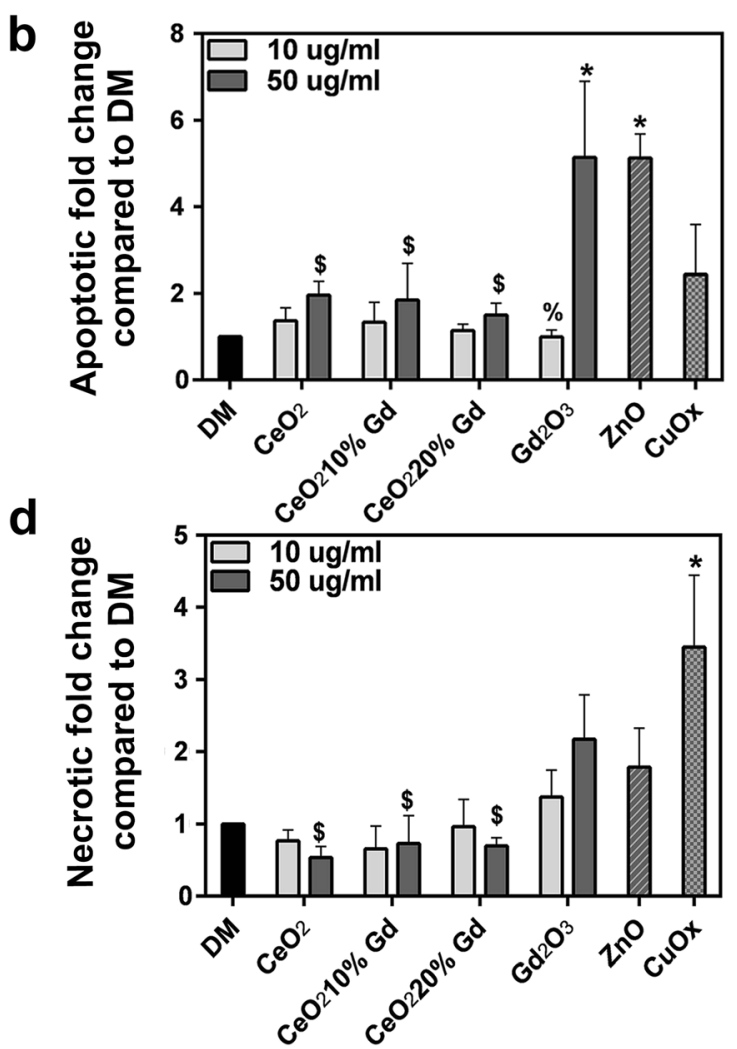

and necrosis, respectively, and DM was used as a negative control. Error bars represent mean \pm standard deviation. $* p<0.05$ compared to control, $\% p<0.05$ compared to $50 \mu \mathrm{g} / \mathrm{ml}, \$ p<0.05$ compared to $\mathrm{Gd}_{2} \mathrm{O}_{3}$ at equivalent dose. b Cells stained positive for annexin V. c Cells stained positive for both annexin $\mathrm{V}$ and propidium iodide. $\mathbf{d}$ Cells stained positive for propidium iodide

in its scavenging abilities when compared to the pure $\mathrm{CeO}_{2}$ and $\mathrm{CeO}_{2} 10 \% \mathrm{Gd}$ (Figs. 6 and 7). Thus, it appears that the valence state of $\mathrm{CeO}_{2}$ is less important in determining antioxidant ability than the capacity of $\mathrm{CeO}_{2}$ to transition between the two valence states. Differences in scavenging ability also existed between the two cell lines; specifically, $\mathrm{CeO}_{2} 20 \% \mathrm{Gd}$ had no significant effect on induced free radicals in NR8383 cells, whereas it was able to significantly reduce hydroxyl radical formation in RLE-6TN cells. While this was unexpected, discrepancies between cell lines are not unusual, especially in $\mathrm{CeO}_{2}$ nanoparticle toxicity studies, and may be the result of differences in cellular physiology and function $[6,24]$. Thus, in these studies, it appears that $\mathrm{CeO}_{2}$ is a less efficient antioxidant in NR8383 cells and that doping has a more pronounced effect on responses of macrophages than those of epithelial cells. The $\mathrm{Gd}_{2} \mathrm{O}_{3}$ had no significant effects on ROS in either EPR model, implying that the antioxidant abilities of the $\mathrm{CeO}_{2}$ are due to the presence of $\mathrm{Ce}^{3+}, \mathrm{Ce}^{4+}$, or oxygen vacancies, and not the dopant.

To ensure that differences in cellular-reactivity were not due to differences in association between the particles and the cells, enhanced dark field microscopy was utilized. All 
of the nanoparticles were capable of associating with both cell types in a matter of minutes (Fig. 3), suggesting that the cells would be capable of responding in the short time course conducted in EPR studies and, further, that measured EPR differences were not due to differences in cellular association. These results were anticipated based on zeta-potential (Table 2) and imply that the presence of Gd did not alter important surface chemistry necessary for interaction of $\mathrm{CeO}_{2}$ with cells. Increased concentrations of $\mathrm{Gd}$ also did not alter the observed size of the nanoparticles (data not shown), implying that differences in reactivity are not a result of differences in size. The hydrodynamic diameters of the $\mathrm{CeO}_{2}$ $10 \% \mathrm{Gd}$ and $\mathrm{CeO}_{2} 20 \% \mathrm{Gd}$ particles in $\mathrm{DM}$ were smaller than the pure $\mathrm{CeO}_{2}$; this difference in hydrodynamic size compared to measured size from SEM is attributed to the sonication of the particle suspensions prior to DLS measurement. Agglomeration is central in nanoparticle-cellular interactions and reactivity [25] and may therefore be important in describing differences in antioxidant potential; however, if agglomeration was important in describing these results, it would also be expected that differences in toxicity between the nanoparticles would be measured. No cytotoxicity was measured in this study; thus, this lack of correlation suggests that the differences in antioxidant abilities are due to valence state and transitional ability rather than variances in nanoparticle agglomeration.

None of the three $\mathrm{CeO}_{2}$ nanoparticles induced significant changes in overall cell viability and did not induce apoptosis or necrosis at $24 \mathrm{~h}$ (Figs. 8 and 9). While the lack of differences between the $\mathrm{CeO}_{2}$ nanoparticles was unexpected, numerous studies have shown a lack of $\mathrm{CeO}_{2}$ reactivity at similar doses $[9,26]$ and have accounted this nontoxic effect to $\mathrm{CeO}_{2}$ transitional ability and presence of $\mathrm{Ce}^{3+/ 4+}$. In agreement, Celardo et al. [9] also reported that doping had no effect on cellular viability, again implying that changes in viability measured in other $\mathrm{CeO}_{2}$ nanoparticle studies are not likely a result of valence state.

To further elucidate the effect of $\mathrm{Gd}_{2} \mathrm{O}_{3}$ on differences in $\mathrm{CeO}_{2}$ toxicity, annexin V/PI dual staining was completed and implied that at a concentration equivalent to the quantity of $\mathrm{Gd}_{2} \mathrm{O}_{3}$ in the $50 \mu \mathrm{g} / \mathrm{ml}$ dose of $\mathrm{CeO}_{2} 20 \% \mathrm{Gd}$, the pure $\mathrm{Gd}_{2} \mathrm{O}_{3}$ caused significant apoptosis at $24 \mathrm{~h}$ in both cell lines (Figs. 8 and 9). In fact, all three $\mathrm{CeO}_{2}$ nanoparticles did not elicit apoptosis. This implies that $\mathrm{Gd}$ did not separate from the doped nanoparticles and interact with the cells to yield the observed effects.

Previous studies have suggested that the valence state of Ce in $\mathrm{CeO}_{2}$ nanoparticles is important in toxicity and ROS production $[3,10]$; however, attempts to elucidate which valence state is important for biological effects are lacking. This study attempted to confirm, through alterations in $\mathrm{CeO}_{2}$ valence state ratio, that a specific valence state is a less important determinant of $\mathrm{CeO}_{2}$ reactivity than the presence of mixed valence state and transitional ability. Overall, our initial findings suggest that doping does not increase toxicity but appears to inhibit $\mathrm{CeO}_{2}$ antioxidant potential in a rapid cellular exposure in support of our hypothesis. Since $\mathrm{CeO}_{2}$ toxicity results greatly differ between in vitro and in vivo models [10, 27-29], further studies will need to be completed to determine the effect of valence state on toxicity in vivo.

Acknowledgments The authors would like to thank Dr. Nikki Marshall for her assistance with flow cytometry and Matthew Duling for his assistance with determination of nanoparticle surface area. The authors would also like to thank Dr. Melissa Badding for insightful discussion.

Funding This project was funded by CDC/NIOSH/HELD Direct funding project (CAN 3927ZJUD) and the National Science Foundation through the Integrative Graduate Education and Research Traineeship (IGERT) program under grant number, DGE-1144676.

Disclaimer The findings and conclusions of this work have not been formally disseminated by NIOSH and should not be construed to represent any agency determination or policy.

Open Access This article is distributed under the terms of the Creative Commons Attribution License which permits any use, distribution, and reproduction in any medium, provided the original author(s) and the source are credited.

\section{References}

1. Cassee FR, van Balen EC, Singh C, Green D, Muijser H, Weinstein J, Dreher K (2011) Exposure, health and ecological effects review of engineered nanoscale cerium and cerium oxide associated with its use as a fuel additive. Crit Rev Toxicol 41(3):213 229. doi:10.3109/10408444.2010.529105

2. Minarchick VC, Stapleton PA, Porter DW, Wolfarth MG, Çiftyürek E, Barger M, Sabolsky EM, Nurkiewicz TR (2013) Pulmonary cerium dioxide nanoparticle exposure differentially impairs coronary and mesenteric arteriolar reactivity. Cardiovasc Toxicol 13(4):323-337

3. Skorodumova N, Simak S, Lundqvist BI, Abrikosov I, Johansson B (2002) Quantum origin of the oxygen storage capability of ceria. Phys Rev Lett 89(16):166601

4. Wang Z, Wang Q, Liao Y, Shen G, Gong X, Han N, Liu H, Chen Y (2011) Comparative study of $\mathrm{CeO} 2$ and doped $\mathrm{CeO} 2$ with tailored oxygen vacancies for CO oxidation. Chem Phys Chem 12(15):27632770. doi:10.1002/cphc.201100346

5. Lin W, Huang Y-W, Zhou X-D, Ma Y (2006) Toxicity of cerium oxide nanoparticles in human lung cancer cells. Int J Toxicol 25(6): 451-457

6. Park E-J, Choi J, Park Y-K, Park K (2008) Oxidative stress induced by cerium oxide nanoparticles in cultured BEAS-2B cells. Toxicology 245(1-2):90-100. doi:10.1016/j.tox.2007.12.022

7. Eom H-J, Choi J (2009) Oxidative stress of $\mathrm{CeO}_{2}$ nanoparticles via p38-Nrf-2 signaling pathway in human bronchial epithelial cell, BEAS-2B. Toxicol Lett 187(2):77-83. doi: 10.1016/j.toxlet.2009.01.028

8. Xia T, Kovochich M, Liong M, Mädler L, Gilbert B, Shi H, Yeh JI, Zink JI, Nel AE (2008) Comparison of the mechanism of 
toxicity of zinc oxide and cerium oxide nanoparticles based on dissolution and oxidative stress properties. ACS Nano 2(10):2121-2134. doi:10.1021/nn800511k

9. Celardo I, De Nicola M, Mandoli C, Pedersen JZ, Traversa E, Ghibelli L (2011) $\mathrm{Ce}^{3+}$ ions determine redox-dependent anti-apoptotic effect of cerium oxide nanoparticles. ACS Nano 5(6):4537-4549. doi:10.1021/nn200126a

10. Das M, Patil S, Bhargava N, Kang J-F, Riedel LM, Seal S, Hickman JJ (2007) Auto-catalytic ceria nanoparticles offer neuroprotection to adult rat spinal cord neurons. Biomaterials 28(10):1918-1925

11. Korsvik C, Patil S, Seal S, Self WT (2007) Superoxide dismutase mimetic properties exhibited by vacancy engineered ceria nanoparticles. Chem Commun 10:1056-1058. doi:10.1039/B615134E

12. Hirano S, Suzuki KT (1996) Exposure, metabolism, and toxicity of rare earths and related compounds. Environ Health Perspect 104(Suppl 1):85-95

13. Hornés A, Gamarra D, Munuera G, Fuerte A, Valenzuela R, Escudero M, Daza L, Conesa J, Bera P, Martínez-Arias A (2009) Structural, catalytic/redox and electrical characterization of systems combining $\mathrm{Cu}-\mathrm{Ni}$ with $\mathrm{CeO}_{2}$ or $\mathrm{Ce}_{1-\mathrm{x}} \mathrm{M}_{\mathrm{x}} \mathrm{O}_{2-\delta}(\mathrm{M}=\mathrm{Gd}$ or $\mathrm{Tb})$ for direct methane oxidation. J Power Sources 192(1):70-77

14. ASTM B922-02: Standard test method for metal powder specific surface area by physical adsorption (2002). ASTM International. American Society for Testing and Materials, West Consohocken, PA

15. Gibbs-Flournoy E, Bromberg P, Hofer T, Samet J, Zucker R (2011) Darkfield-confocal microscopy detection of nanoscale particle internalization by human lung cells. Part Fibre Toxicol 8(1):2

16. Porter D, Sriram K, Wolfarth M, Jefferson A, Schwegler-Berry D, Andrew ME, Castranova V (2008) A biocompatible medium for nanoparticle dispersion. Nanotoxicology 2(3):144-154. doi:10.1080/17435390802318349

17. Leonard S, Chen B, Stone S, Schwegler-Berry D, Kenyon A, Frazer D, Antonini J (2010) Comparison of stainless and mild steel welding fumes in generation of reactive oxygen species. Part Fibre Toxicol 7(1):32

18. Dunnick K, Badding MA, Schwegler-Berry DE, Patete J, Koenigsmann C, Wong S, Leonard SS (2014) The effect of tungstate nanoparticles on reactive oxygen species and cytotoxicity in RAW 264.7 mouse monocyte macrophage cells. J Toxic Environ Health A. doi:10.1080/15287394.2014.897490

19. Kumar A, Babu S, Karakoti AS, Schulte A, Seal S (2009) Luminescence properties of europium-doped cerium oxide nanoparticles: role of vacancy and oxidation states. Langmuir 25(18):10998-11007

20. Kuntaiah K, Sudarsanam P, Reddy BM, Vinu A (2013) Nanocrystalline $\mathrm{Ce}_{1-\mathrm{x}} \mathrm{Sm}_{\mathrm{x}} \mathrm{O}_{2-\delta}(\mathrm{x}=0.4)$ solid solutions: structural characterization versus CO oxidation. RSC Adv 3(21):7953-7962. doi:10.1039/C3RA23491F

21. Riddick T (1968) Control of colloid stability through zeta potential: with a closing chapter on its relationship to cardiovascular disesase

22. Cheng G, Guo W, Han L, Chen E, Kong L, Wang L, Ai W, Song N, Li H, Chen H (2013) Cerium oxide nanoparticles induce cytotoxicity in human hepatoma SMMC-7721 cells via oxidative stress and the activation of MAPK signaling pathways. Toxicol In Vitro 27(3): 1082-1088. doi:10.1016/j.tiv.2013.02.005

23. Acharya SA, Gaikwad VM, D'Souza SW, Barman SR (2014) Gd/Sm dopant-modified oxidation state and defect generation in nano-ceria. Solid State Ionics 260:21-29. doi:10.1016/j.ssi.2014.03.008

24. Li N, Wang M, Oberley TD, Sempf JM, Nel AE (2002) Comparison of the pro-oxidative and proinflammatory effects of organic diesel exhaust particle chemicals in bronchial epithelial cells and macrophages. J Immunol 169(8):4531-4541. doi:10.4049/jimmunol.169.8.4531

25. Tedja R, Marquis C, Lim M, Amal R (2011) Biological impacts of $\mathrm{TiO}$ on human lung cell lines A549 and H1299: particle size distribution effects. J Nanoparticle Res 13(9): 3801-3813. doi:10.1007/s11051-011-0302-6

26. Demokritou P, Gass S, Pyrgiotakis G, Cohen JM, Goldsmith W, McKinney W, Frazer D, Ma J, Schwegler-Berry D, Brain J (2013) An in vivo and in vitro toxicological characterisation of realistic nanoscale $\mathrm{CeO}_{2}$ inhalation exposures. Nanotoxicology 7(8):13381350

27. Ma JY, Mercer RR, Barger M, Schwegler-Berry D, Scabilloni J, Ma $\mathrm{JK}$, Castranova V (2012) Induction of pulmonary fibrosis by cerium oxide nanoparticles. Toxicol Appl Pharmacol 262(3):255-264

28. Srinivas A, Rao PJ, Selvam G, Murthy PB, Reddy PN (2011) Acute inhalation toxicity of cerium oxide nanoparticles in rats. Toxicol Lett 205(2):105-115. doi:10.1016/j.toxlet.2011.05.1027

29. Colon J, Hsieh N, Ferguson A, Kupelian P, Seal S, Jenkins DW, Baker CH (2010) Cerium oxide nanoparticles protect gastrointestinal epithelium from radiation-induced damage by reduction of reactive oxygen species and upregulation of superoxide dismutase 2 . Nanomed Nanotechnol 6(5):698-705 